\title{
THE EFFECT OF CALF STARTER RATION FOR PRE-WEANING ONGOLE GRADE (PO) CALVES ON BODY WEIGHT GAIN
}

\author{
E. Winarti and A. Widyastuti \\ Yogyakarta Assessment Institute of Agricultural Technology \\ Jl. Stadion Maguwoharjo No. 22 Sleman, Yogyakarta - Indonesia \\ Corresponding E-mail : ernawinarti@gmail.com
}

Received January 11, 2016; Accepted July 21, 2016

\begin{abstract}
ABSTRAK
Pengkajian bertujuan untuk mengetahui pengaruh pemberian calf starter pada pedet pra sapih terhadap pertambahan bobot badan harian dan biaya pakan per kenaikan bobot badan. Dua puluh ekor pedet PO umur 1 bulan dibagi kedalam 4 kelompok perlakuan pakan, masing-masing perlakuan 5 ekor. Perlakuan (P1) diberi pakan tambahan menir kedelai 100\%; (P2) menir kedelai 50\% + Gliricidia 50\%; (P3) menir kedelai 50\% + katul 50\%; (P4) menir kedelai 50\%+ roti afkir 50\%. Pemberian calf starter diberikan pada umur 1 bulan hingga 3 bulan. Pengamatan dilakukan terhadap pertambahan bobot badan harian pedet. Rancangan yang digunakan adalah Rancangan Acak Lengkap. Data dianalisa dengan analisa Variansi dan dilanjutkan Uji Beda Nyata Terkecil. Hasil analisa statistik menunjukkan bahwa perlakuan pakan berpengaruh nyata $(\mathrm{P}<0,05)$ terhadap pertambahan bobot badan harian pedet. Hasil pengkajian dapat disimpulkan bahwa pemberian calf starter dengan menir kedelai $100 \%$ memberikan pertambahan bobot badan harian pedet pra sapih paling tinggi yaitu sebesar $0,70 \mathrm{~kg}$.

Kata Kunci : Pedet pra sapih, calf starter
\end{abstract}

\begin{abstract}
The objective of study was to determine the effect of calf starter in the pre-weaning calves against the daily body weight gain. Twenty Ongole grade (PO) calves age of 1 month divided into 4 treatment groups of feed, 5 calves for each treatment. Treatment (P1) fed with extra soybean groats; (P2) soybean groats $50 \%+$ Gliricidia $50 \%$; $(\mathrm{P} 3)$ soybean groats $50 \%+$ rice bran $50 \%$; $(\mathrm{P} 4)$ soybean groats $50 \%+$ rejected bread 50\%. Calf starter was given at age 1 month to 3 months. Observation was carried out on calves daily weight gain. This experiment was designed in Completely Randomized Design. Data was analyzed by analysis of variance and continued Least Significant Difference Test. Statistical analysis showed that feed of $(\mathrm{P}<0.05)$ significantly affected the daily weight gain of the calves. Results of the study can be concluded that calf starter with soya groats provide the best daily weight gain of preweaning calf.
\end{abstract}

Keywords: pre-weaning calf, calf starter

\section{INTRODUCTION}

Growth, health and performance of calves depend on many environmental, management and feeding factors. This short paper of starter feed for calves of dairy breeds, pre-weaning. One measure of success in breeding beef cattle is a daily body weight gain pre-weaning calf. The Government through the Indonesian Center for Animal Research and Development (ICARD) has targeted daily weight gain pre-weaning calves was $0.4 \mathrm{~kg}$ Ongole grade (PO) cattle, $0.3 \mathrm{~kg}$ Bali cows and 
$0.8 \mathrm{~kg}$ crossing (Badan Litbang Pertanian, 2007). Daily weight gain pre-weaning calves in Livestock Regional Technical Implementation Unit was $0.61 \mathrm{~kg}$ (Rasyid and Efendy, 2014). Report of Affandhy et al. (2010) showed that the body weight gain in Ongole grade pre-weaning calves at the farm people is still low at $0.261 \pm$ $0.190 \mathrm{~kg}$.

One effort to increase body weight daily to match the set target is the improvement of nutrient consumed in pre-weaning calf. Nutrient deficiency in this period, as well as stunted growth will also lead to lower immunity and are susceptible to diseases that lead to the death of the calf (Sharma and Jain, 1979). Improvement of nutrient consumed for calves can be done by giving milk substitutes to overcome the lack of mother's milk or the provision of calf starter to increase nutrient intake for calves. Intake of starter rom young calves depends first of all on the quantity of consumed milk or milk replace, but also on composition, palatability and physical form of starter feeds (Fokkink et al., 2010; Pezhveh et al., 2014).

Calf starter is concentrated to the initial growth nutrient dense, low crude fiber and soft textured. Calf Starter granting a transition period of consumption of milk with dry feed intake. Calf starter is very important for a healthy rumen development and growth of a good body, so the success in this period will determine the growth of calves in the next period. Several researchers have recommended the addition of ground hay to the starter for optimum rumen development (Anderson et al., 1987; Beharka et al., 1998; Coverdale et al., 2004; Greenwood et al., 1997; Waterman 2005). However some researcher and extentionists (Heinrichs and Lesmeister 2000) reported that hay is not recommended for calves until weaning time when calves weaned 3-6 weeks, since it is less energy dense per unit than grain.

Feed ingredients to prepare, besides the high quality of calf starter, should also be available in the market at relatively low prices. In order to generate the increase in calf daily gain of $0.4 \mathrm{~kg}$, feed must contain protein $22.4 \%$, while for daily weight gain of $0.6 \mathrm{~kg}$ is needed protein in the feed of $26.6 \%$ and for body weight daily $0.8 \mathrm{~kg}$ is needed protein in feed 27.4\% (Van Amburgh and Drakley, 2005). Trials by Akayezu et al. (1994), Luchini et al. (1991), and Hill et al. (2007) substantiate that $18 \% \mathrm{CP}$ diets are adequate.

One of the feed material of high quality and the price is relatively cheap soya groats. Groats soya is the residue of sorting soy consumption, usually in the form of worm-eaten leftover soybean, seed is not full or immature seed. Soy nutrient content is very high, with a protein content of $40.3 \%, 16.7 \%$ fat and $3.2 \%$ fiber (Hermana, et al., 1996). The protein sources in starter feeds are also important for the growth and development of calves. Soybean meal (SBM) is one of the most commonly used protein sources in calf starters (Davis and Drackley, 1998; MillerCushon et al., 2014a), because calves prefer soybean meal over sunflower meal, dry distillers grain with solubles (DDGS) or canola meal (Montoro et al., 2010; Miller-Cushon et al., 2014a; Miller-Cushon et al., 2014b). The use of soybean meal as a protein source in calf starter at the age of 4 days calf can be weaned at the age of 45 days and resulted in both the performance at the age of 6 months (Yusof et al., 1998).

Other feed ingredients are widely available on the market including the bran. Rice bran is a byproduct of the rice mills with a crude protein content of $11.19 \%$, fat $11.22 \% 13.85 \%$ crude fiber and energy metabolism of $1630 \mathrm{kcal} / \mathrm{kg}$ (Rizal et al., 2005). Other food sources that contain high nutritional is Gliricidia sepium. Gliricidia sepium is a plant that is easy to grow quickly in the tropics. Gliricidia sepium leaves the crude protein content is as high as 24.22\% (Bakrie, 1996), whereas the results Munier (2010), Gliricidia sepium protein content of $18.3 \%, 38.2 \%$ crude fiber and crude fat $2.8 \%$.

Expired-bread or toast rest of the market is pretty much available in the market. Nutrient content is quite high and the prices are relatively cheap, allowing the expired-bread become one of the feed material. Chalimi et al. (2010) states that the energy digestibility of culled better bread than rice bran and feasible given as feed for Ongole grade. The protein content of bread rejects BETN $12.63 \%$ and $78.42 \%$ (Diyatmoko et al., 2010), while according to Agus, et al. (2005) rejects the bread protein content of $5.1 \%$ and $91.4 \%$ organic ingredients.

The aim of this study was to determine daily weight gain and feed cost per weight increase in pre-weaning Ongole grade calf given calf starter composed of different materials.

\section{MATERIALS AND METHODS}

Twenty Ongole grade (PO) calves age of 1 month is divided into 4 treatment of feed. 
Treatment ration (P1) soya groats 100\%; (P2) soya groats $50 \%+$ gliricidia $50 \%$; (P3) groats bran soybeans $50 \%+50 \%$; (P4) groats soybeans $50 \%+50 \%$ expired-bread. The nutrient content of the feed materials making up rations is shown in Table 1. The content of nutritional ration in each treatment is shown in Table 2. The supplementary feed is given as much as $0.5 \mathrm{~kg} /$ day at the age of $1-2$ months and $1 \mathrm{~kg} /$ day at age 2-3 month. Soya groats and Gliricidia leaves before boiling is given in calves done beforehand. During the observation, calves kept with their mothers and left calf suckling mother. Weight of calves weighed at the age of 1 month and 3 months of age. Daily weight gain is calculated using the formula:

$$
\mathrm{G}=(\mathrm{W} 2-\mathrm{W} 1) / 60
$$

Where

$\mathrm{G}$ : Daily weight gain

W2 : 3 months old calf weight $(\mathrm{kg})$

W1 : The weight of calves aged 1 month $(\mathrm{kg})$

Daily weight gain data were analyzed by analysis of variance, if there are differences continued with Least Significant Difference Test
(Steel and Torrie, 1981). To determine the cost of calf starter most efficient treatment then calculated feed cost per gain (cost of feed for every increase in body weight) of each treatment. Feed cost per gain is calculated using the formula:

$$
\mathrm{FC}=(\mathrm{TC} \times \mathrm{P}) / \mathrm{I}
$$

Where

FC : Feed cost per gain

TC : Total consumption of calf starter for 60 days $(\mathrm{kg})$

$\mathrm{P} \quad$ : price of calf starter (IDR/ $\mathrm{kg}$ )

I : The increase in body weight during the 60 days $(\mathrm{kg})$

\section{RESULTS AND DISCUSSION}

\section{The development of body weight}

Calf weight at 3 months showed that treatment P1 (100\% soy groats) is higher (93.6 $\mathrm{kg}$ ), compared to P2 (soybean groats $50 \%+$ gliricidia 50\%) amounted to $78.6 \mathrm{~kg}$; P3 (soyben groats $50 \%$ + rice bran $50 \%$ ) amounted to $81.6 \mathrm{~kg}$ and P4 (soybean groats $50 \%+$ rejected bread $50 \%$ ) of $75.4 \mathrm{~kg}$ (Figure 1). Feed by using $100 \%$

\begin{tabular}{|c|c|c|c|}
\hline Feed Ingredients & Crude Protein & Crude Fat & Crude Fiber \\
\hline & \multicolumn{3}{|c|}{ 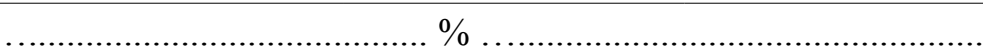 } \\
\hline Soya groats* & 30.9 & 9.4 & 14.4 \\
\hline Bran* & 9.8 & 7.2 & 17.2 \\
\hline Gliricidia** $^{* *}$ & 18.3 & 2.8 & 38.2 \\
\hline Expired-bread* & 6.1 & 7.5 & 4.7 \\
\hline
\end{tabular}

Table 1. Nutrient Content of Feed Ingredients for Calf Starter

* Laboratory analysis by Chem-mix Pratama, Yogyakarta

** Munier (2010)

Table 2. Calf Starter Nutrient by Ration Treatment

\begin{tabular}{lcccc}
\hline \multirow{2}{*}{ Components } & \multicolumn{4}{c}{ Rations Treatments } \\
\cline { 2 - 5 } & P1 & P2 & P3 & P4 \\
\hline Crude Protein (\%) & 30.9 & 24.6 & 20.3 & 18.5 \\
Crude Fat (\%) & 9.4 & 6.1 & 8.3 & 8.5 \\
Crude Fiber (\%) & 14.4 & 26.3 & 15.8 & 9.6 \\
\hline
\end{tabular}

$\mathrm{P} 1=100 \%$ soya groats; $\mathrm{P} 2=$ soya groats $50 \%+$ gliricidia $50 \% ; \mathrm{P} 3=$ soya groats $50 \%+$ rice bran $50 \% ; \mathrm{P} 4$ $=$ soya groats $50 \%+$ expired bread $50 \%$ 
soya groats it protein content is highest (30.9\%) compared to other treatments, so the calf is also the highest growth.

The growth of the calf's body weight is influenced by feed intake and nutrient content of feed. By knowing the feed intake and nutrient content of feed can be seen the consumption of nutrients. Feed intake (dry matter), crude protein, crude lipid and crude fiber are listed in Table 3. Table 3 shows that treatment P1 protein consumption is highest $(11.83 \mathrm{~kg})$ compared to the P2 $(9.68 \mathrm{~kg})$ treatment, P3 $(7.91 \mathrm{~kg})$ and P4 $(7.25 \mathrm{~kg})$. Likewise, crude fat consumption, amounting to $3.60 \mathrm{~kg}$ treatment $\mathrm{P} 1$ is also more than the treatment P2 $(2.40 \mathrm{~kg}) ; \mathrm{P} 3(3.23 \mathrm{~kg})$ and
P4 $(3.33 \mathrm{~kg})$, this led to the growth of the calf on the treatment P1 is higher than other treatments.

The growth of the calf between the treatment P1, P2 and P3 are not different, because nutrient consumption is almost the same. Treatment P2 consumption of $9.68 \mathrm{~kg}$ crude protein, higher than treatment $\mathrm{P} 3$ and $\mathrm{P} 4$ respectively amounted to $7.91 \mathrm{~kg}$ and $7.25 \mathrm{~kg}$, but it is accompanied by the consumption of crude fat P2 lower $(2.40 \mathrm{~kg})$ compared to P3 and P4 are respectively of $3.23 \mathrm{~kg}$ and $3.33 \mathrm{~kg}$. Similarly, consumption of crude fiber in treatment $\mathrm{P} 2$ higher $(10.34 \mathrm{~kg})$ than treatment P3 and P4 respectively amounted to $6.15 \mathrm{~kg}$ and $3.76 \mathrm{~kg}$. This resulted in the growth of the calf between the treatment P1, P2 and P3 are the same.

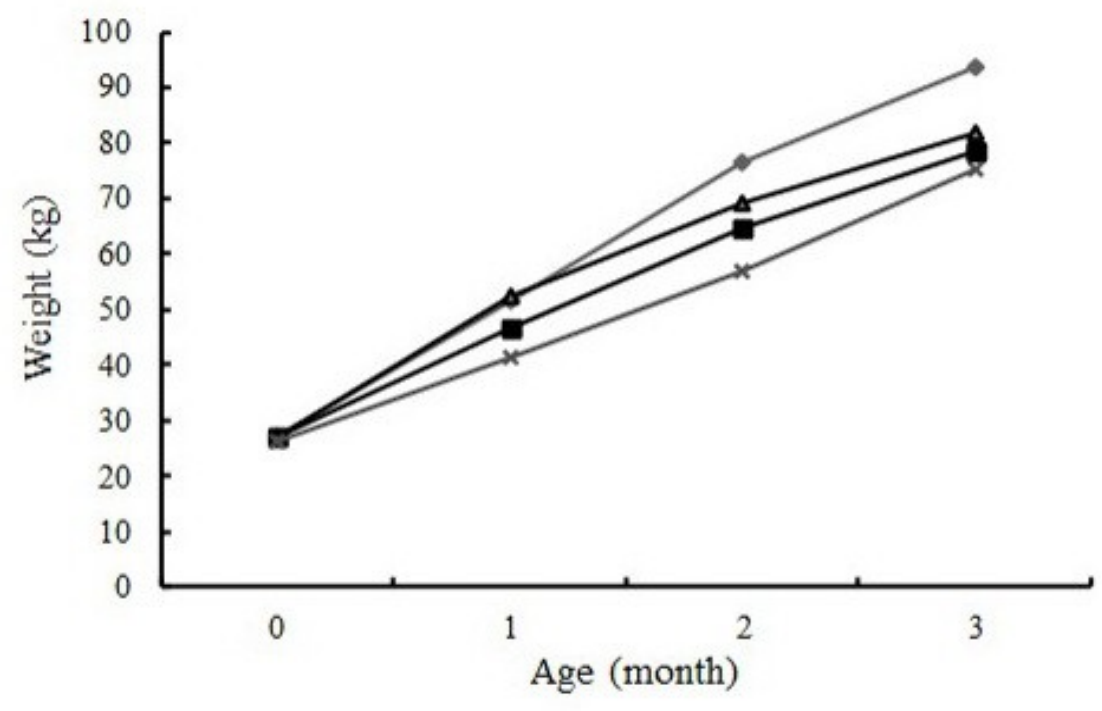

Figure 1. Graph of body weight development of the calf by calf starter with different materials Symbols represent $100 \%$ soybean groats $(\bullet)$, soybean groats $50 \%+$ gliricidia $50 \%(\boldsymbol{\bullet})$, soybean groats $50 \%+$ rice brans $50 \%(\boldsymbol{\Delta})$ and soybean groats 50\% + expired-bread 50\% $(\times)$

Table 3. Consumption of Dry Matter, Crude Protein, Crude Fat and Crude Fiber

\begin{tabular}{|c|c|c|c|c|}
\hline \multirow{2}{*}{ Treatment } & \multirow{2}{*}{$\begin{array}{l}\text { Consumption of } \\
\text { Dry Matter (kg) }\end{array}$} & \multicolumn{3}{|c|}{ Consumption of nutrients } \\
\hline & & Crude Protein (kg) & Crude Fat (kg) & Crude of Fibers (kg) \\
\hline \multicolumn{5}{|c|}{ 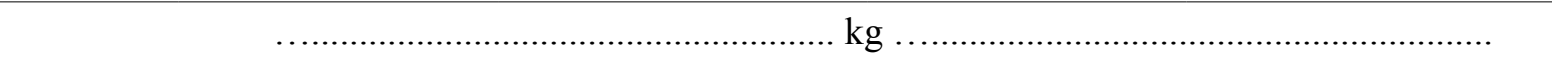 } \\
\hline $\mathrm{P} 1$ & 38.29 & 11.83 & 3.60 & 5.51 \\
\hline $\mathrm{P} 2$ & 39.33 & 9.68 & 2.40 & 10.34 \\
\hline P3 & 38.95 & 7.91 & 3.23 & 6.15 \\
\hline $\mathrm{P} 4$ & 39.17 & 7.25 & 3.33 & 3.76 \\
\hline
\end{tabular}

$\mathrm{P} 1=100 \%$ soya groats; $\mathrm{P} 2=$ soya groats $50 \%+$ gliricidia $50 \% ; \mathrm{P} 3=$ soya groats $50 \%+$ rice bran $50 \% ; \mathrm{P} 4$ $=$ soya groats $50 \%+$ expired bread $50 \%$ 


\section{Daily Weight Gain}

The mean daily weight gain calf row succession was $0.70 \mathrm{~kg}(\mathrm{P} 1) ; 0.53 \mathrm{~kg}$ (P2); 0.49 $\mathrm{kg}$ (P3) and $0.57 \mathrm{~kg}$ (P4) (Table 4). Statistical analysis showed that the P1 (soybean groats $100 \%$ ) has the most daily weight gain higher than the other treatments $(\mathrm{P}<0.05)$, whereas among treatments P2, P3 and P4 showed no significant differences. Body weight gain were higher in treatment $\mathrm{P} 1$ due to the high nutrient content, especially the protein content is $30.9 \%$, while the protein content of treatment P2, P3 and P4 respectively $24.6 \% ; 20.3 \%$ and $18.5 \%$ (Table 2 ). High protein content in the treatment $\mathrm{P} 1$ is also followed by the consumption of crude protein and crude fat treatment is higher than P2, P3 and P4 (Table 3).

Calves daily weight gain of all the treatment have been above the government's target. The Government through the Indonesian center for Animal Research and Development target body weight daily pre-weaning calves to cows $\mathrm{PO}$ was $0.4 \mathrm{~kg}$ (Badan Litbang Pertanian, 2007). This suggests that to achieve the targets that have been set by the Government, farmers can choose one of four kinds of diets in these studies.

\section{Calf Feed Costs for Body Weight Gain}

Total feed intake $0.75 \mathrm{~kg} / \mathrm{head} / \mathrm{day}$, and results of calculation of calf feed costs required for each increase of $1 \mathrm{~kg}$ of body weight (without taking into account the condition of the parent) treatment $\mathrm{P} 1, \mathrm{P} 2, \mathrm{P} 3$ and $\mathrm{P} 4$ respectively - were IDR 4,285; IDR 3,537; IDR 4,591 and IDR 3,970 (Table 5). The data in Table 5 shows that the combination of soya groats and Gliricidia (P2) is the most efficient. This is indicated by the cheapest feed costs of IDR 3,537 for every $1 \mathrm{~kg}$ increase in body weight. This is because the price of the cheapest feed ration price compared to other treatments, but still shows a relatively high increase in body weight $(31.8 \mathrm{~kg})$. Gliricidia nutrient content is quite high and low prices resulted in a combination of soya groats and gliricidia most feed efficient than other treatments.

Table 4. Daily Gain of Ongole Grade Calf Fed on Different Treatment

\begin{tabular}{lllll}
\hline & \multicolumn{4}{c}{ Treatments } \\
\cline { 2 - 5 } & P1 & P2 & P3 & P4 \\
\hline Weights at month 1 $(\mathrm{kg})$ & 51.6 & 46.8 & 52.2 & 41.4 \\
Weights at month 3 $(\mathrm{kg})$ & 93.6 & 78.6 & 81.6 & 75.4 \\
Daily weight gain, $(\mathrm{kg} /$ day) & $0.70^{\mathrm{b}}$ & $0.53^{\mathrm{a}}$ & $0.49^{\mathrm{a}}$ & $0.57^{\mathrm{a}}$ \\
\hline
\end{tabular}

${ }^{\mathrm{ab}}$ superscripts in the same column indicate significant differences $(\mathrm{P}<0.05)$

$\mathrm{P} 1=100 \%$ soya groats; $\mathrm{P} 2=$ soya groats $50 \%+$ gliricidia $50 \% ; \mathrm{P} 3=$ soya groats $50 \%+$ rice bran $50 \% ; \mathrm{P} 4$ $=$ soya groats $50 \%+$ expired bread $50 \%$

Table 5. Feed Cost for Increasing of a Kilogram of Calf Body Weight

\begin{tabular}{lrrrr}
\hline \multirow{2}{*}{ Items } & \multicolumn{4}{c}{ Treatments } \\
\cline { 2 - 5 } & \multicolumn{1}{c}{ P1 } & \multicolumn{1}{c}{ P2 } & \multicolumn{1}{c}{ P3 } & P4 \\
\hline Body weight gain of age 1-3 months (kg) & 42.0 & 31.8 & 29.4 & 34.0 \\
Feed prices (IDR/kg) & 4,000 & 2,500 & 3,000 & 3,000 \\
Feed cost for 2 months (IDR) & 180,000 & 112,500 & 135,000 & 135,000 \\
Feed cost for an increasing of body weight (IDR/kg) & 4,285 & 3,537 & 4,591 & 3,970 \\
\hline
\end{tabular}

$\mathrm{P} 1=$ Soya Groats $100 \% ; \mathrm{P} 2=$ Soya Groats $50 \%+$ Gliricidia $50 \% ; \mathrm{P} 3=$ Soya Groats $50 \%+$ rice brans $50 \%$; $\mathrm{P} 4=$ Soya Groats $50 \%+$ Expired-bread $50 \%$ 


\section{CONCLUSION}

The use of Soybean Groats in the ration preweaning calf (calf starter) shows the daily body weight gain were the highest, but when viewed from an economic standpoint, the combination of soybean groats and Gliricidia leaves are most efficient.

\section{REFERENCES}

Affandhy, L., A. Rasyid and N.H. Krishna. 2010. Pengaruh perbaikan manajemen pemeliharaan pedet sapi potong terhadap kinerja reproduksi induk pasca beranak (Study kasus pada sapi induk PO di uasaha ternak rakyat Kabupaten Jawa Tengah. Prosiding Seminar Nasional Teknologi Peternakan dan veteriner. Pusat Penelitian dan Pengembangan Peternakan, Bogor, 3-4 Agustus 2010. P. 40-46.

Agus, A., B. Suwignyo and R. Utomo. 2005. Penggunaan complete feed berbasis jerami padi fermentasi pada sapi Australian commercial cross terhadap konsumsi nutrien dan pertambahan bobt badan harian. Buletin Peternakan. 29(1): 1 - 9 .

Akayezu, J. M., J. G. Linn, D. E. Otterby, W. P. Hansen, and D. G. Johnson. 1994. Evaluation of calf starters containing different amounts of crude protein for growth of Holstein calves. J. Dairy Sci. 77: 1882-1889.

Anderson K L, T.G. Nagaraja, J.L. Morrill, T.B. Avery, S.J. Galitzer and J.E. Boyer. 1987. Ruminal microbial development in conventionally or early-weaned calves. J. Anim. Sci. 4: 1215-1226

Bakrie, B. 1996. Feeding management of ruminant livestock in Indonesia. In: Ruminant nutrition and production in the tropics and subtropics. Australian centre for International Agricultural research, Canberra.

Badan Libang Pertanian. 2007. Prospek dan arah pengembangan sapi. Badan Penelitian dan Pengembangan Pertanian.

Beharka, A.A.,T.G. Nagaraja, J.L. Morrill, G.A. Kennedy and R.D. Klemm. 1998. Effects of form of the diet on anatomical, microbial, and fermentative development of the rumen of neonatal calves. J. Dairy Sci. 81: 19461955

Chalimi, K., A. Rochim, E. Purbowati,
Soedarsono, E. Rianto and A. Purnomoadi. 2010. Kelayakan roti sisa pasar sebagai pakan alternatif berdasar pemanfaatan kecernaan energi dan parameter darah pada sapi Peranakan Ongole. Prosiding Seminar Nasional Teknologi Peternakan dan Veteriner. Pusat Penelitian dan Pengembangan Peternakan, Bogor, 13-14 Agustus 2009. P. 100-106

Coverdale, J. A., H.D. Tyler, J.D. Quigle, and J.A.Brumm 2004. Effect of various levels of forage and form of diet on rumen development and growth in calves. J. Dairy Sci. 87: 2554-2562

Davis, C.L. and J.K. Drackley. 1998. Starter feed: Importance composition, and intake. The Development, Nutrition, and Management of the Young Calf. Iowa State University Press, Ames 283-206.

Diyatmoko, A., M.R.H. Fitrianto, E. Purbowati, M. Arifin and A. Purnomoadi. 2010. Pemanfaatan protein pakan dan produksi protein mikroba pada sapi Peranakan Ongole (PO) yang diberi pakan sisa pasar sebagai pengganti dedak padi. Prosiding Seminar Nasional Teknologi Peternakan dan Veteriner. Pusat Penelitian dan Pengembangan Peternakan, Bogor, 13-14 Agustus 3009. P. 220 - 225

Fokkink, W.B., T.M. Hill, H.G. Bateman, J.M. Aldrich, R.L. Schlotterbeck and A.F. Kertz. 2010. Simulated straw bedding intake and effect of high and low cereal grain starters on rumen development of neonatal Holstein calves. Journal of Animal Science. 88: ESuppl.2, 300-301

Greenwood, R.H., J.L. Morrill, E.C. Titgemeyer and G.A. Kennedy. 1997. A new method of measuring diet abrasion and its effect on the development of the fore-stomach. J. Dairy Sci. 80: 2534- 2541

Heinrichs, A. J. and K. Lesmeister. 2000. Why you should hold off on feeding forage to calves. Hoard's Dairyman 145: 638

Hermana, M., Karmini and D. Karyadi. 1996. Healthsignificance of tempe for human nutrition. Proceedings of the second International Soybean Processing and Utilization Conference. Funny Publishing limited Partnership. Bangkok, Thailand. January 8-13, 1996. P. 391-394

Hill, T.M., J.M. Aldrich, R.L. Schlotterbeck and H.G. Bateman II. 2007. Protein concentrations for starters fed to transported 
neonatal calves. Professional Animal Scientist. 23(2):123-134.

Luchini, N. D., S. F. Lane and D. K. Combs. 1991. Evaluation of starter crude protein level and feeding regime for calves weaned at 26 days of age. J. Dairy Sci. 74: 39493955.

Miller-Cushon, E.K., M. Terré, T.J. DeVries and A. Bach. 2014a. The effect of palatability of protein source on dietary selection in dairy calves. J. Dairy Sci. 97: 4445-4454.

Miller-Cushon, E.K., C. Montoro, I.R. Ipharraguerre and A. Bach. 2014b. Dietary preference in dairy calves for feed ingredients high in energy and protein. J. Dairy Sci. 97: 1534-1544.

Montoro, C., I. Ipharraguerre and A. Bach. 2010. Determination of oro-sensorial preference of protein ingredients in starters in weaned calves. J. Dairy Sci. 93, E-Suppl.1, p 422.

Munier. F.F. 2010. Bobot hidup kambing betina Peranakan Etawah (PE) yang diberikan pakan tambahan daun gamal (Gliricidia sepium) dan kultur buah kakao (Theobroma cocoa L.). Prosiding Seminar Nasional Teknologi Peternakan dan Veteriner. Pusat Penelitian dan Pengembangan Peternakan. Bogor. 3 - 4 Agustus 2010. P.586-592

Pezhveh, N., G.R. Ghorbani, P. Rezamand and M. Khorvash. 2014. Effects of different physical forms of wheat grain in corn-based starter on performance of young Holstein dairy calves. J. Dairy Sci. 97: 6382-6390.

Rasyid, A. and Efendy, J. 2014. Bobot lahir dan bobot sapih pedet hasil turunan pejantan sapi PO terpilih di Unit Pelaksana Teknis Daerah Budidaya Ternak. Prosiding Seminar Nasional Teknologi Peternakan dan Veteriner. Pusat Penelitian dan Pengembangan Peternakan. Malang. 12 14 Agustus 2014.. P. 55-60

Rizal, Y., D. Tami and V. Rahmadian. 2005. Pengaruh penggantian sebagian bungkil kedelai dengan daun ubi kayu yang difermentasi dengan Aspergillus niger dalam ransum terhadap performa ayam broiler. Buletin Peternakan. 29 (3) : 106-111

Sharma, K.N.S. and D.K. Jain. 1979. Dairy Handbook. Karnal, India.

Steel, R.G.D dan J.H. Torrie. 1981. Principles and Procedures of Statistics, a Biometrical Approach. International Student Ed. McGraw-Hill Book Company.

Van Amburgh, M. and J. Drakley. 2005. Current perspectives on the energy and protein requirements of the pre weaned calf. Chapter 5 in calf and heifer rearing. P.C. garnsworty. Ed. Nottingham University Press, Nort, UK

Waterman, D.F. 2005. Sources of nutrients for milk replacers and dry starter feeds and what factors impact quality. NRAES-175, Cooperative Extension, pp. 96-115

Yusof, S.M., Fadzil, K.H. Teoh dan S. Abas.1998. Early weaning of calves on milk replacer fed either soyabean or fishmeal based calf starter. Malaysia J. Anim Sci. 3(1): 40-46. 